\title{
Anti-CD20 therapies for multiple sclerosis: current status and future perspectives
}

\author{
Monica Margoni ${ }^{1,6} \cdot$ Paolo Preziosa ${ }^{1,2} \cdot$ Massimo Filippi ${ }^{1,2,3,4,5} \cdot$ Maria A. Rocca ${ }^{1,2,5}$ (])
}

Received: 7 July 2021 / Revised: 2 August 2021 / Accepted: 3 August 2021 / Published online: 11 August 2021

(c) Springer-Verlag GmbH Germany, part of Springer Nature 2021

\begin{abstract}
Multiple sclerosis (MS) is a chronic inflammatory, demyelinating and neurodegenerative disease affecting the central nervous system (CNS), often characterized by the accumulation of irreversible clinical disability over time. During last years, there has been a dramatic evolution in several key concepts of immune pathophysiology of MS and in the treatment of this disease. The demonstration of the strong efficacy and good safety profile of selective B-cell-depleting therapies (such as anti-CD20 monoclonal antibodies) has significantly expanded the therapeutic scenario for both relapsing and progressive MS patients with the identification of a new therapeutic target. The key role of B cells in triggering MS disease has been also pointed out, determining a shift from the traditional view of MS activity as largely being 'T-cell mediated' to the notion that MS-related pathological processes involve bi-directional interactions between several immune cell types, including $\mathrm{B}$ cells, both in the periphery and in the CNS. This review provides an updated overview of the involvement of B cells in the immune pathophysiology and pathology of MS. We summarize the rationale regarding the use of anti-CD20 therapies and the results of the main randomized controlled trials and observational studies investigating the efficacy and safety profile of rituximab, ocrelizumab, ofatumumab and ublituximab. Suggestions regarding vaccinations and management of MS patients during COVID-19 pandemic with anti-CD20 therapies are also discussed. Finally, therapies under investigation and future perspectives of anti-CD20 therapies are taken into consideration.
\end{abstract}

Keywords Multiple sclerosis · Anti-CD20 therapy $\cdot$ Randomized clinical trials $\cdot$ Disease modifying therapy $\cdot$ B cells

Maria A. Rocca

rocca.mara@hsr.it

1 Neuroimaging Research Unit, Division of Neuroscience, IRCCS San Raffaele Scientific Institute, Milan, Italy

2 Neurology Unit, IRCCS San Raffaele Scientific Institute, Milan, Italy

3 Neurorehabilitation Unit, IRCCS San Raffaele Scientific Institute, Milan, Italy

4 Neurophysiology Service, IRCCS San Raffaele Scientific Institute, Milan, Italy

5 Vita-Salute San Raffaele University, 20132 Milan, Italy

6 Multiple Sclerosis Center of the Veneto Region, Department of Neurosciences, University Hospital-School of Medicine, Padua, Italy

\section{Introduction}

Multiple sclerosis (MS) is a chronic, inflammatory, demyelinating and neurodegenerative disease affecting the central nervous system (CNS), often leading to the accumulation of irreversible clinical disability.

During recent years, there has been a dramatic evolution in the arsenal of MS treatments.

Among the developed therapies, anti-CD20 monoclonal antibodies mediating B-cell depletion, such as rituximab, ocrelizumab and ofatumumab, have received increasing attention. The demonstration of the strong efficacy and good safety profile of these selective B-cell-depleting therapies [1-3] has significantly contributed to expand the therapeutic scenario to treat MS patients.

An increasing amount of data regarding the use of antiCD20 therapies has emerged. Accordingly, an updated overview is currently needed to summarize the most relevant findings supporting B-cell involvement in MS immune pathophysiology as well as the main results regarding 
pharmacology, efficacy and safety of such therapies obtained from the most recent randomized controlled trials (RCTs) and observational studies. Guidelines for the proper timing of vaccinations and recent evidence about the risk of COVID-19 disease in association with anti-CD20 therapies are also discussed. Finally, future perspectives of antiCD20 therapies and new promising anti-B-cell treatments are described.

\section{Methods}

We review the most recent evidence regarding the involvement of B cells in the immune pathophysiology and pathology of MS, the rationale underlying the use of anti-CD20 therapies and the results of the main RCTs and observational studies investigating the efficacy and safety profile of antiCD20 therapies currently available.

References for this Review were identified through searches of PubMed with the search terms 'adverse event(s)', 'antigen-presenting cell', 'atrophy', 'B-cell', 'blood', 'Bruton tyrosine kinase', 'CD19', 'CD20', 'COVID-19', 'cerebrospinal fluid', 'demyelination', 'depleting therapy(ies)', 'disability', disease activity', 'disease-modifying', 'gadolinium-enhancing lesion(s)', 'immunoglobulin', 'immunology', 'inebilizumab', 'infusion reaction(s)', 'lymphocyte', 'malignancy(ies)', 'monoclonal antibody(ies)', 'MRI', 'multiple sclerosis', 'ocrelizumab', 'ofatumumab', 'outcomes', 'overall drug persistence', 'pathology', 'phenotype(s)', 'prediction', 'progression', 'primary progressive', 'randomized controlled trial', 'relapse', 'relapsing-remitting', 'rituximab', 'safety', 'SARS-CoV2', 'secondary progressive', 'T-cell', 'T2-hyperintense lesion(s)', 'tolebrutinib', 'treatment', 'ublituximab', 'vaccination' from 1 January 1979 to 5 July 2021. Articles were also identified through searches of the authors' own files. Abstract presented at main congresses in the field were also evaluated. Only papers published in English were reviewed. The final reference list was generated on the basis of originality and relevance to the broad scope of this Review, with a focus on articles published during the past 3 years.

\section{The role of B cells in MS immune pathophysiology}

Historically, the classical view of MS immune pathophysiology, based on the convergence of studies from MS patients and experimental models, supposed that bouts of MS inflammatory activities are principally mediated by aberrantly activated and/or dysregulated pro-inflammatory CNS-reactive T effector (Teff) CD4 + cells (including T helper 1 [Th1], interleukin-17 [IL-17]-expressing CD4
[Th17], granulocyte-macrophage colony-stimulating factor [GM-CSF] expressing CD4) and CD8 $+\mathrm{T}$ cells (including IL-17-expressing CD8 [Tc17], GM-CSF expressing CD8, and mucosal-associated invariant T-cell receptor [TCR]expressing $\mathrm{CD} 8^{+}$cells). By trafficking into the CNS, these cells are supposed to cause perivascular demyelination, glial cell activation and neuro-axonal injury $[4,5]$.

During the last few years, there has been a dramatic evolution in several key concepts of MS immune pathophysiology. One update involves a shift from the traditional view of MS disease activity as largely being 'T-cell mediated' to the view that MS relapses involve key bi-directional interactions between several immune cell types, including B cells, both in the periphery and in the CNS $[4,6]$.

This updated conceptual framework of the cellular immunology underlying MS activity has occurred after the demonstration of the strong efficacy of selective B-cell-depleting therapies (such as anti-CD20 monoclonal antibodies), pointing out the key role of B cells in triggering MS disease activity $[1-3,7]$.

The original impetus for targeting B cells in MS was based on the long-standing recognition of abnormally produced antibodies in the CNS of patients with MS (e.g., increased immunoglobulin [Ig] synthesis rates, cerebrospinal fluid (CSF)-restricted oligoclonal bands, antibodies bound to myelin fragments within phagocytic cells in the CNS parenchyma, Ig and complement detection in demyelinated lesions) [8-11].

Of note, B cells, plasmablasts and plasma cells are increased in the CSF of MS patients and their number is positively associated with intrathecal inflammation and Ig synthesis [12]. Despite this, the antigenic targets of the aberrant immune cell activation in MS remain incompletely defined and the long-term contribution of autoantibodies is largely unknown. Historically, the focus of investigation has been on myelin proteins, such as myelin basic protein (MBP), proteolipid protein (PLP) and myelin oligodendrocyte glycoprotein (MOG) [6, 13]. However, studies of circulating antibodies in MS patients including those directed against myelin antigens (MBP, MOG) [14] and the inward rectifying potassium channel (Kir) $4.1[15,16]$ have not led to the same pathogenic implications of specific CNS-directed antibodies, as those recognized in other conditions such as anti-aquaporin 4 (AQP4) antibodies in neuromyelitis optica spectrum disorders (NMOSD) or anti-MOG associated disease (MOGAD).

Growing evidence suggests that antibody-independent functions of B cells play key roles in mediating disease activity. B cells have been demonstrated to contribute to cascades of cellular immune interaction in the periphery, to act as antigen presenting cells (APCs) to T cells, thus promoting T-cell activation and proliferation, to interact with APCs to influence antigen trafficking, and to be directly involved in 
the production of cytokines and chemokines exerting both anti- and pro-inflammatory actions and contributing to oligodendrocyte and neuronal damage (Fig. 1) [4, 6].

B cells are well-known efficient APCs, characterized by the expression of class-II major histocompatibility complex (MHC class II), and specialized in capturing soluble and membrane-tethered antigens, with a higher efficiency in presenting antigens and activating T cells than non-B-cell APCs $[6,17]$. Due to the possible relevant role of B cells in processing CNS antigens, B cells could promote an increased activation of Teff, thanks to strong B-cell-T-cell interactions mediated by more than 20 co-stimulatory molecule-receptor pairs, with CD80/86 and their T-cell-activating binding partner CD28 being among the best characterized [6]. In addition to expressing co-stimulatory molecules, B cells can also express co-inhibitory molecules involved in downregulating the responses of Teff, such as the programmed death ligand 1 (PD-L1) and its receptor, programmed death 1 (PD-1) [6].

In MS, B cells are also recognized to have not only an abnormal propensity to produce pro-inflammatory cytokines (interleukin 6 [IL-6], GM-CSF, tumor necrosis factor alpha [TNF- $\alpha]$, and lymphotoxin alpha [LT- $\alpha]$ ), but also a deficient capacity to produce regulatory cytokines (such as interleukin 35 [IL-35], and transforming growth factor beta [TFG- $\beta$ ]) $[4,6,18-22]$. Due to such an abnormal cytokine response profile, B cells can induce aberrant pro-inflammatory Th1, Th17 and myeloid cell responses, contributing to the cellular immune cascades involved in disease activity [4, 6, 18-22].

\section{B cells in MS pathology}

Pathological studies have consistently shown that B cells significantly contribute to MS pathology in the CNS [23-27]. B-cell infiltrates are significantly higher in MS compared with other inflammatory CNS diseases, especially in patients at early stages of MS and with active lesions.

In early and active focal demyelinating lesions, CD20 ${ }^{+}$ $\mathrm{B}$ cells are mainly located focally in the perivascular space of only one or a few larger veins and have pro-inflammatory functions (Fig. 1) [23, 24]. Conversely, a more abundant plasma cell infiltrate can be found in the perivascular space and in the meninges from patients with progressive MS (Fig. 1) [23, 24]. This evidence suggests a gradual differentiation of infiltrating B cells into a stable plasma cell population, showing expression of markers involved in B-cell survival and plasmablast differentiation (CD27 and CD38) $[23,24]$.

In addition to cascades of the peripheral cellular immune interactions contributing to 'relapse biology', there is also an important role for a 'CNS-compartmentalized' inflammation that sustains chronic inflammation, demyelination, and neurodegeneration, which can be maintained in the absence of ongoing relapse biology.

This 'CNS-compartmentalized' inflammation is characterized by prominent B-cell-rich inflammatory aggregates resembling tertiary lymph follicles that can be found in the meninges of MS patients, mainly within deep cortical sulci, but also in the perivascular spaces (Fig. 1). These inflammatory aggregates in the CNS may provide an environment that fosters B-cell homing, survival and functional activation $[28,29]$, and, in turn, contribute to degenerative mechanisms [30].

For instance, the extent of meningeal inflammation and the levels of pro-inflammatory cytokines (e.g., interferon gamma [IFN- $\gamma$ ], TNF- $\alpha$, LT- $\alpha$, IL- 6 ) in the CSF of MS patients have been associated with the severity of subpial cortical demyelination, promoting also a graded pattern of neuronal loss and microglial activation consistent with a 'surface-in' process possibly mediated by one or more toxic substances contained in the CSF [25-27, 31, 32].

\section{Mechanisms of action of anti-CD20 therapies}

CD20 is a transmembrane, non-glycosylated phosphoprotein of 33-37 kDa that is expressed in tetramers associated with lipid rafts on the surface of cell lineage from pre-B cells to naïve and memory B cells (Fig. 2) [33].

Monoclonal antibodies directed against specific targets typically deplete targeted cells through at least four possible different mechanisms: (i) antibody-dependent cellular cytotoxicity (ADCC); (ii) complement-dependent cytotoxicity (CDC); (iii) antibody-dependent cellular phagocytosis (ADCP); and (iv) induction of cell apoptosis. Currently available anti-CD20 monoclonal antibodies induce B-cell depletion mainly through ADCC, CDC and ADCP [33].

The infusion of anti-CD20 monoclonal antibodies promotes a depletion of $\mathrm{CD} 20^{+} \mathrm{B}$ cells within hours, mainly occurring in the liver [34]. Such a depletion reaches the nadir typically after 8 weeks and can be sustained for several weeks to months according to the posology and the features of the specific anti-CD20 monoclonal antibody.

After anti-CD20 therapies, B-cell repopulation starts in bone marrow and spleen, followed by blood, with a different rate between memory $\mathrm{B}$ cells and $\mathrm{CD} 19^{+}$cells [35].

Of note, B-cell counts are usually determined using CD19, which largely overlaps with CD20 during B-cell differentiation, because it is less prone to potential interference in presence of anti-CD20 monoclonal antibodies [35].

B-cell reappearance can be defined when $\mathrm{CD} 19^{+} \mathrm{B}$ cells reach $1 \%$ of lymphocyte counts [36]; however, other criteria are also applied, including $2 \%$ of $\mathrm{CD} 19^{+} \mathrm{B}$ cells [36]. 
A

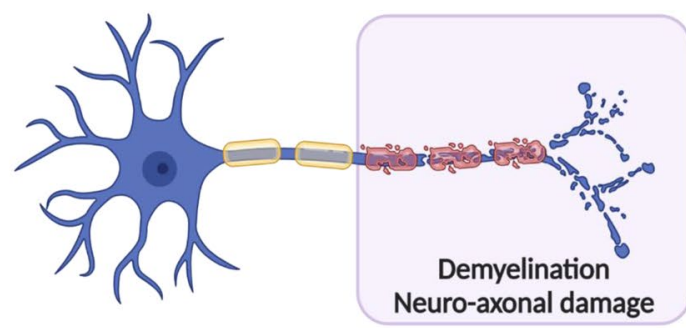

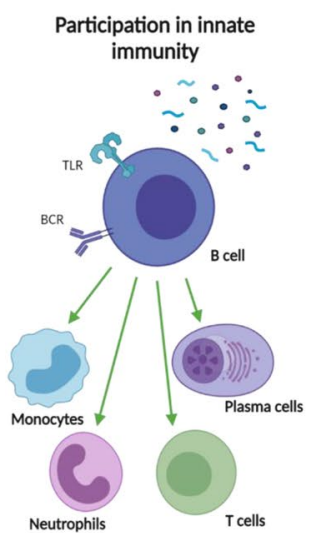

B

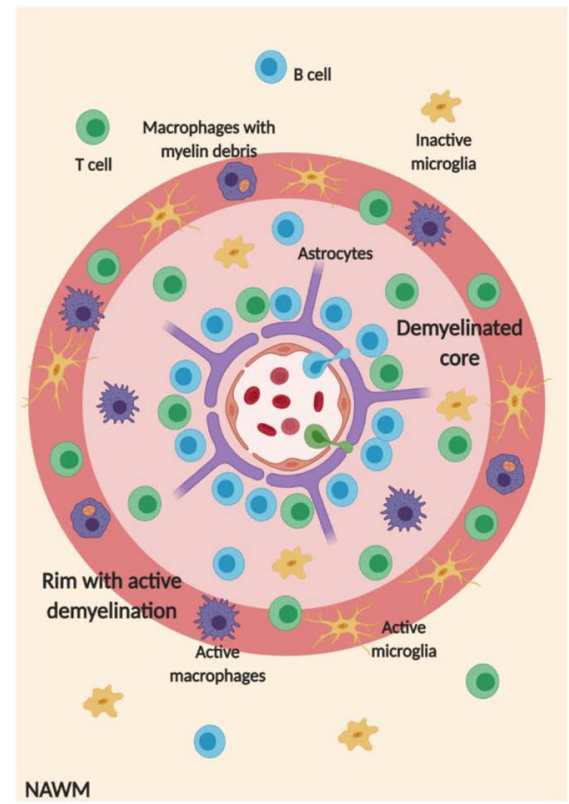

C
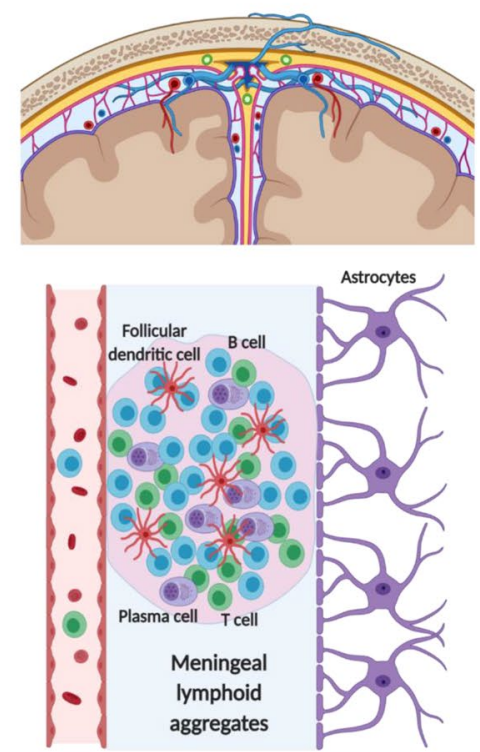

Fig. 1 Summary of the involvement of B cells in the immune pathophysiology and pathology of MS. A Roles of B cells in immunity and disimmunity. In MS, B cells are involved in innate immunity, antigen presentation, production of regulatory and pro-inflammatory cytokines, chemokines and autoantibodies. B, C Overview of the distribution of B cells in the different CNS areas involved in MS pathology. B In an active MS lesion with a central inflamed vein, a demyelinated core, with microglia and macrophages, and a rim of active ongoing demyelination with activated microglia, macrophages with different stages of myelin degradation, and oligodendrocyte injury, the highest density of lymphocytes is seen in the perivascular space of the central vein, with the majority of B cells in the lesion present at this site. C Aggregates of B cells can also be observed in the leptomeninges. This compartmentalized inflammation, characterized by the development of ectopic follicle-like lymphoid aggregates, is mainly driven by B cells, plasma cells, $\mathrm{T}$ cells and follicular dendritic cells. Created with biorender.com. See text for further details. $B C R$ B-cell receptor, Breg regulatory B-cell, Ig immunoglobulin, GM-CSF granulocyte-macrophage colony-stimulating factor, $I L-6$ interleukin 6, IL-10 interleukin $10, I L-35$ interleukin $35, M H C$ class $I I$ major histocompatibility complex class II, $N A W M$ normal-appearing white matter, $P D-L 1$ ligand programmed death ligand $1, T C R$ T-cell receptor, $T_{\text {eff }}$ effector T-cell, TFG- $\beta$ transforming growth factor beta, TLR Toll-like receptor, $T N F-\alpha$ tumor necrosis factor alpha 


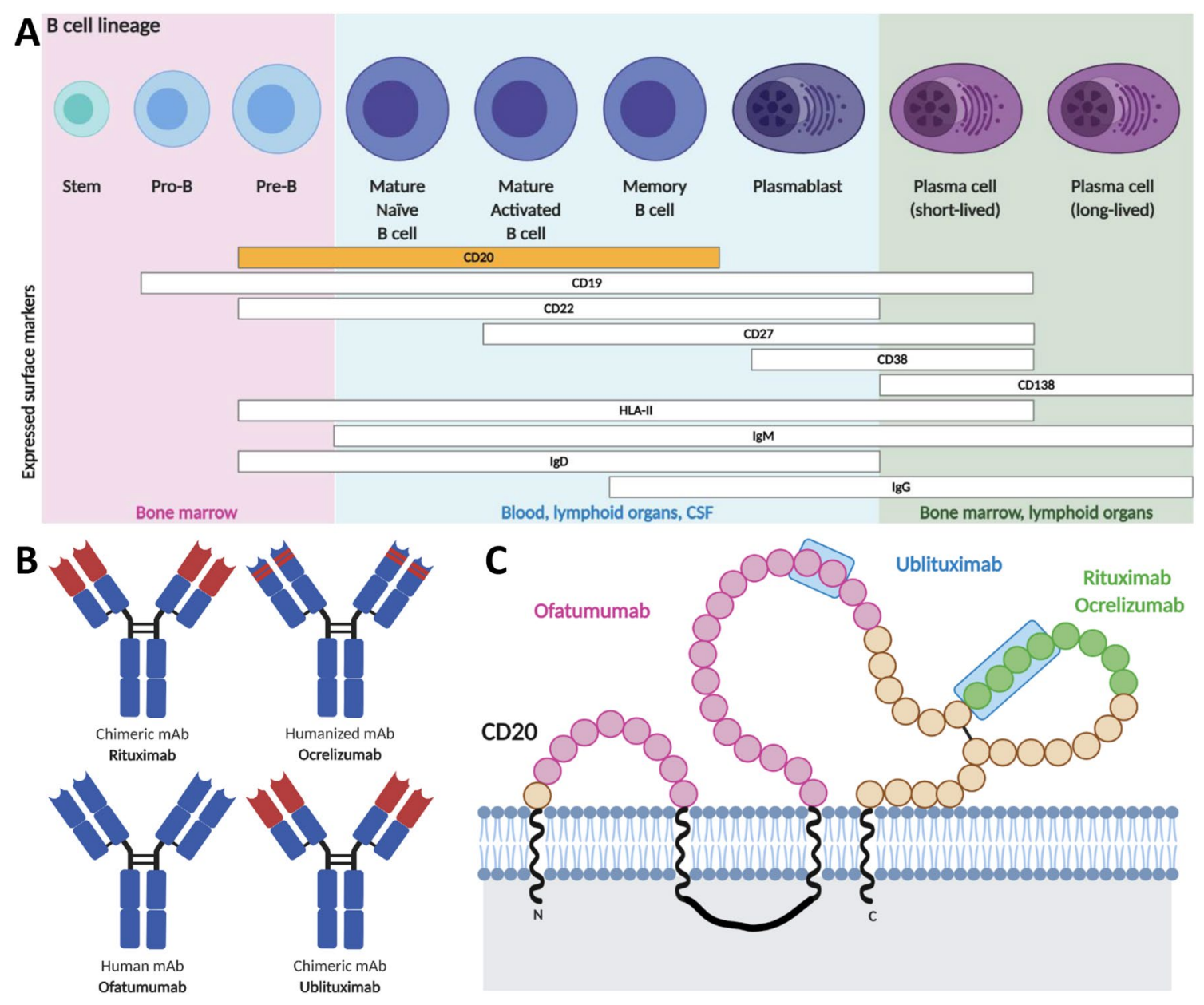

Fig. 2 B-cell lineage, main anti-CD20 monoclonal antibodies and their targeted CD20 epitopes. A Summary of the B-cell maturation stages, defined according to the expression of specific cellsurface antigens. CD20 is expressed in pre-B cells, mature and memory B cells. Of note, both early and late maturation stages are not depleted since they do not express CD20, thus B-cell repopulation and humoral immune memory are preserved. B Structure of the

\section{Efficacy of anti-CD20 therapies}

\section{Rituximab}

Rituximab is a chimeric monoclonal antibody that is commonly prescribed in highly active MS patients, although it is not approved from Food and Drug Administration (FDA) nor European Medicines Agency (EMA) for use in MS (Fig. 2).

Its efficacy has been investigated in several studies as summarized in Table 1.

In particular, in a 48-week phase-II RCT (HERMES), 104 relapsing-remitting (RR) MS patients were randomized to receive either a single administration of i.v. rituximab $1000 \mathrm{mg}$ or placebo on days 1 and 15 [1]. Compared with placebo, patients who received rituximab had a lower ARR at week $24(p=0.04)$, not confirmed at week $48(p=0.08)$, different anti-CD20 monoclonal antibodies used in MS. C Schematic overview of the different CD20 epitopes recognized by each specific anti-CD20 monoclonal antibody. Created with biorender.com. See text for further details. CSF cerebrospinal fluid, HLA-II human leukocyte antigen II, $I g D$ immunoglobulin D, $I g G$ immunoglobulin G, $I g M$ immunoglobulin $\mathrm{M}, m A b$ monoclonal antibody

and a reduction of T2-hyperintense lesion volume (LV) from baseline to week $24(p=0.008)$ and $36(p=0.004)$. From week 12, rituximab also reduced Gadolinium (Gd)-enhancing lesions $(p \leq 0.003)$.

The efficacy of rituximab has been also evaluated in a 96-week phase-II/III RCT of 439 primary progressive (PP) MS patients (OLYMPUS) [37]. Rituximab (two i.v. administrations of $1000 \mathrm{mg} 2$ weeks apart) was not associated with changes in the proportion of patients developing confirmed disease progression (CDP) $(p=0.14)$, the primary outcome of the study, nor in brain atrophy rate $(p=0.62)$. However, it promoted a significant lower increase of $\mathrm{T} 2$-hyperintense LV at week $96(p<0.001)$ compared with placebo [37]. In a subgroup analysis, rituximab showed a delayed time to CDP in younger PPMS patients (aged $<51$ years) or those with Gd-enhancing lesions at baseline. An additive predictive 


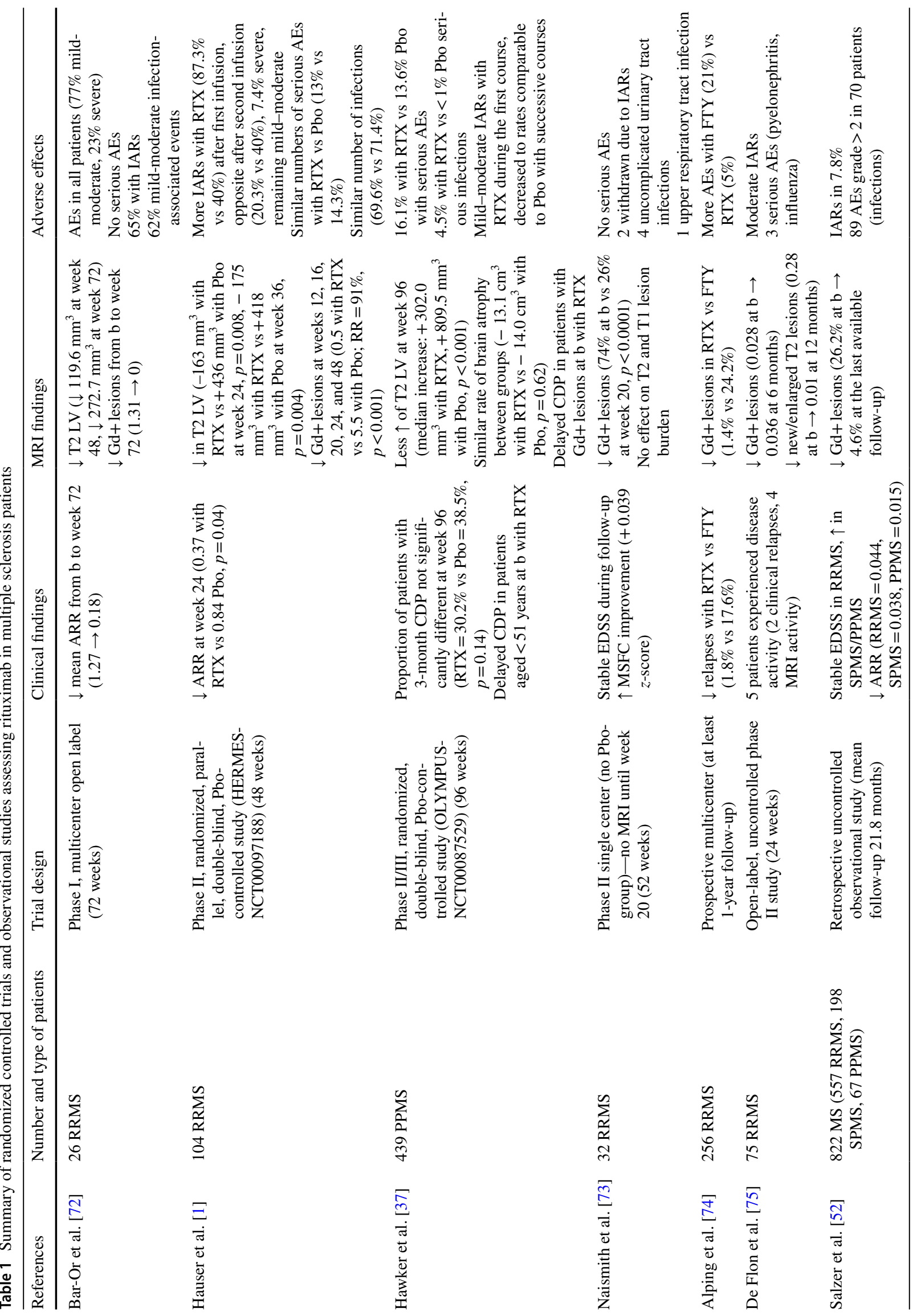




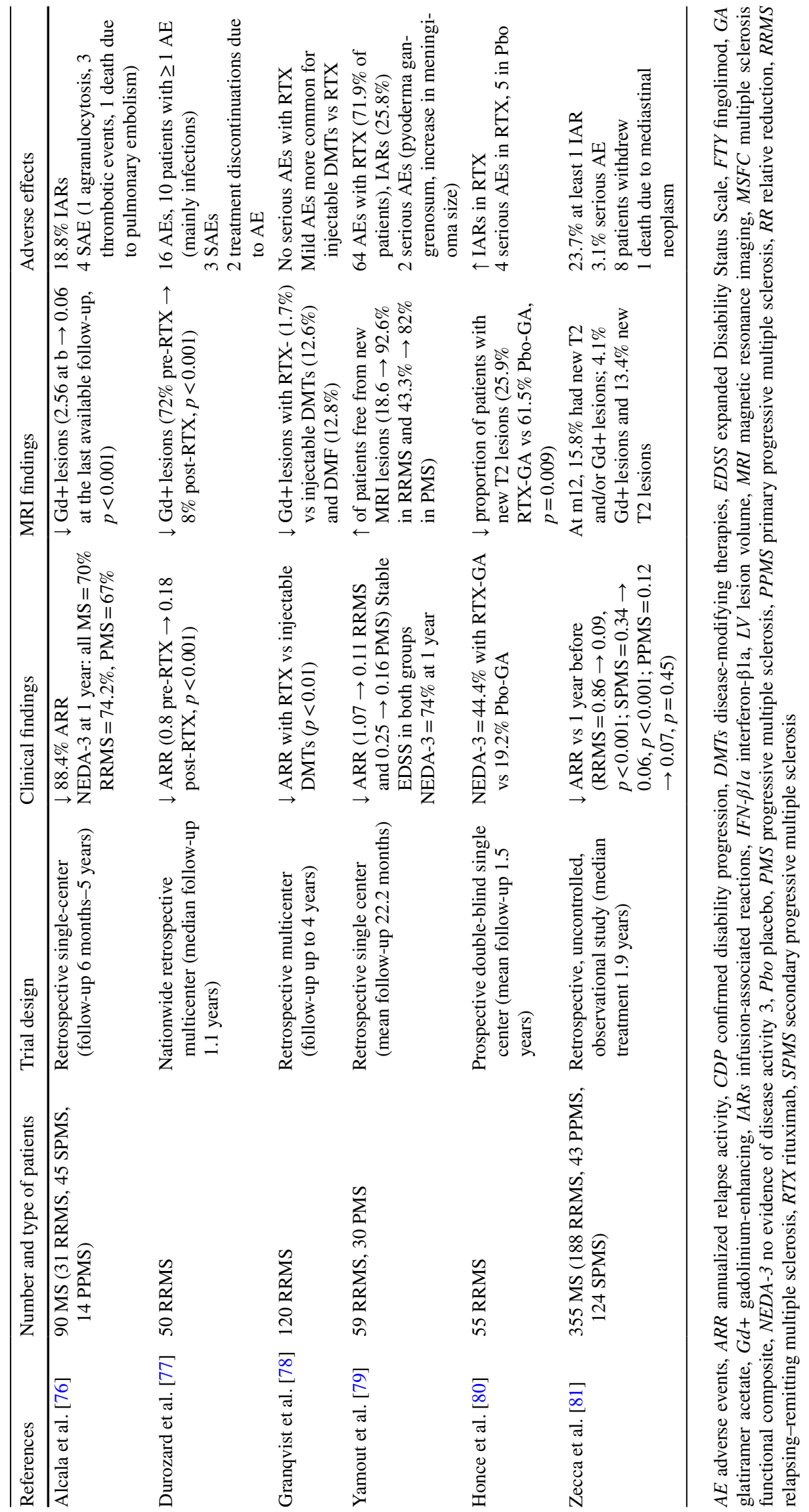


effect of age and Gd-enhancing lesions at baseline was found, suggesting that B-cell depletion might be effective in PPMS patients who are younger and have higher inflammatory activity [38].

Although further exploration of efficacy has not been carried out in phase-III RCTs, several other observational studies have confirmed a significant reduction of disease activity with rituximab (Table 1).

Few studies have utilized an intrathecal approach to administer rituximab to target compartmentalized inflammation in progressive MS. In an open-label study in eight progressive MS patients with MRI evidence of meningeal inflammation, a significant and sustained reduction in circulating B cells and a transient drop in CSF B cells were observed, but this did not translate in a change in the number or appearance of leptomeningeal enhancement [39].

\section{Ocrelizumab}

Ocrelizumab is a humanized anti-CD20 monoclonal antibody (Fig. 2) approved by the FDA (March 2017) and EMA (January 2018), at a dose of $600 \mathrm{mg}$ i.v. twice yearly, as a therapy for the treatment of highly active relapse-onset MS and PPMS with evidence of disease activity.

A first phase-II RCT explored ocrelizumab efficacy in RRMS patients, assigned to either i.v. low (600 mg; $n=55$ ) or high (2000 mg; $n=55$ ) ocrelizumab administrations divided into two doses on days 1 and 15, i.v. placebo $(n=54)$ or weekly intramuscular (i.m.) INF $\beta-1 \mathrm{a}(30 \mu \mathrm{g} ; n=54)$ (Table 2) [40]. RRMS patients treated with ocrelizumab showed a significantly lower ARR (0.13 in the low- and 0.17 in the high-dose group) compared with placebo (0.64) and INF $\beta$-1a (0.36) group [40]. Change in T2-hyperintense LV did not differ among groups at week 24 ( $p=0.2$ in the low- and high-dose groups; $p=0.5$ in the INF $\beta$-1a-group), whereas the total number of Gd-enhancing lesions was significantly lower in ocrelizumab groups compared with placebo- and INF $\beta$-1a groups (both $p<0.001$ ).

At week 24 , patients initially treated with placebo, $600 \mathrm{mg}$ ocrelizumab and i.m. INF $\beta-1 \mathrm{a}$ received $600 \mathrm{mg}$ of ocrelizumab, whereas the $2000 \mathrm{mg}$ ocrelizumab group received $1000 \mathrm{mg}$ of ocrelizumab. An interim analysis of the open-label extension (OLE) phase showed a maintained low ARR in ocrelizumab groups (0.06 vs 0.07 in the placebo/ ocrelizumab group and 0.07 in the INF $\beta$ - 1 a/ocrelizumab group) over 96-144 weeks [41].

Two identical, phase-III RCTs, including 821 (OPERA I) and 835 (OPERA II) RRMS patients [2], further demonstrated ocrelizumab efficacy (Table 2). Patients were randomized (1:1) to i.v. ocrelizumab $600 \mathrm{mg}$ every 24 weeks or subcutaneous (s.c.) IFN $\beta-1 \mathrm{a} 44 \mu \mathrm{g}$ three times per week over 96 weeks. Compared with IFN $\beta-1 a$, ocrelizumab showed a higher reduction of ARR $(p<0.001)$, a lower prevalence of 12-week CDP $(p<0.05)$, and lower numbers of new/enlarged T2-hyperintense and Gd-enhancing lesions $(p<0.001)$ [2]. The proportion of RRMS patients with 12-week confirmed disability improvement was also higher with ocrelizumab compared with IFN $\beta-1 \mathrm{a}$, being significant in the OPERA I $(p=0.01)$ but not in the OPERA II $(p=0.40)$ [2]. Percentage of brain volume loss from week 24 to 96 was significantly lower in ocrelizumab- vs IFN- $\beta$-1a-group in the OPERA I $(p=0.004)$, but not in the OPERA II $(p=0.09)$ [2].

In the 3-year follow-up OLE [42], the cumulative proportion of patients with 24-week CDP was lower in patients who initiated ocrelizumab earlier vs those initially receiving IFN $\beta$-1a $(p=0.014)$. ARR did not differ between RRMS patients continuing ocrelizumab and those receiving ocrelizumab after switching from IFN $\beta-1 \mathrm{a}(p \geq 0.70)$; both groups attained an almost complete and sustained suppression of brain MRI lesion activity.

The proportion of RRMS patients with no evidence of disease activity 3 (NEDA-3) (i.e., no relapses, no disability progression, no new/enlarged T2-hyperintense or Gdenhancing lesions) was also significantly higher in ocrelizumab groups compared with the INF $\beta$ - 1 a groups both in OPERA I and OPERA II $(p<0.001)$ [43]. In the OLE period, the proportion of patients with NEDA-3 was $65.4 \%$ in patients continuously treated with ocrelizumab compared with $55.1 \%$ in those switching from IFN $\beta-1$ a to ocrelizumab $(p<0.001$, relative difference $=19 \%)$.

Some preliminary results of the open-label, prospective, single-arm, phase-IIIb ENSEMBLE study showed that early RRMS (disease duration $\leq 3$ years) treated with ocrelizumab had a high NEDA-3 rate (84.8\%) after 1 year of treatment [44]. Similarly, a high 2-year NEDA-3 rate $(74.9 \%)$ was detected in the primary analysis of the phase-IIIb CASTING trial, which evaluated ocrelizumab efficacy in RRMS patients with prior suboptimal response to one or two disease-modifying therapies (DMTs) (Table 2) [45].

Ocrelizumab has been the first DMT showing significant effects in PPMS, as demonstrated in the phase-III RCT (ORATORIO), which evaluated 732 PPMS patients receiving either i.v. ocrelizumab $(600 \mathrm{mg})(n=488)$ or placebo $(n=244)$ every 24 weeks for at least 120 weeks [2]. Ocrelizumab reached the primary study endpoint since it was associated with a significant reduction of 12-week CDP $(p=0.03)$ compared with placebo, further confirmed with the 24-week CDP ( $p=0.04)$ [2]. The prevalence of worsening on timed 25-foot walk test (25-FWT) was also significantly reduced with ocrelizumab $(p=0.04)$ [2]. Brain T2-hyperintense LV decreased with ocrelizumab and increased with placebo from baseline to week $120(p<0.001)$, and the rate of brain atrophy was significantly lower with ocrelizumab compared with placebo $(p=0.02)$ [2].

Similarly to rituximab, a post hoc analysis (pooled OPERA studies) suggested that patients who were younger 


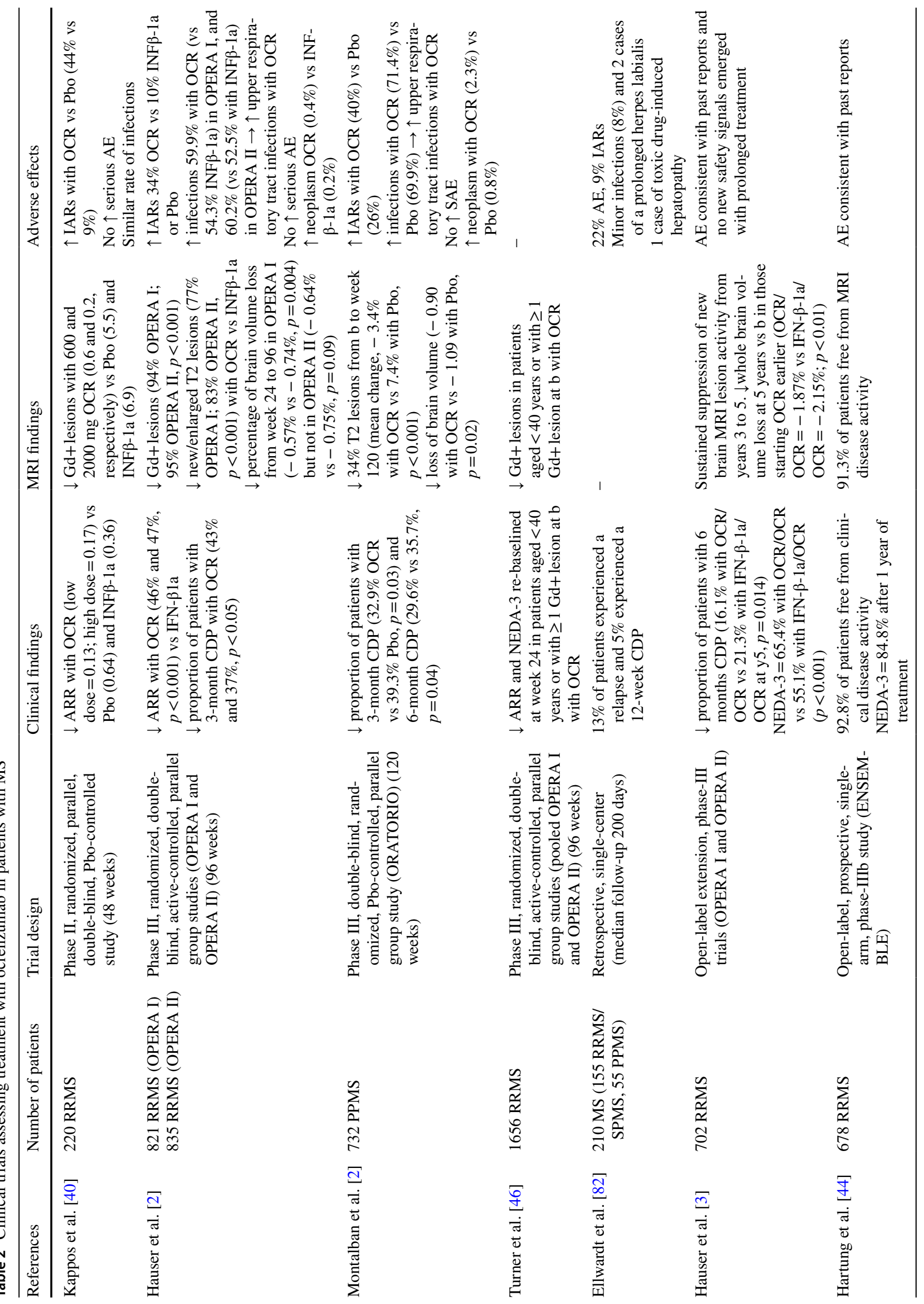




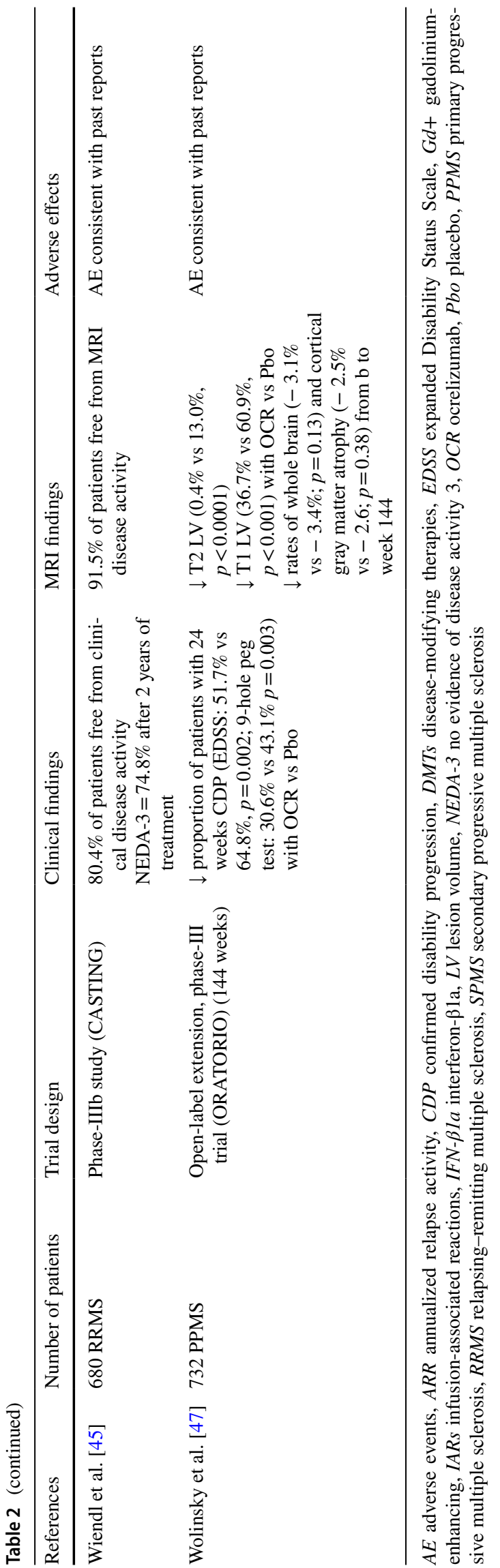

(aged $<40$ years) and with baseline disease activity $(\geq 1$ Gd-enhancing lesions) had a greater treatment benefit with ocrelizumab, relative to IFN $\beta$-1a, than patients who were older and with inactive disease [46].

An interim report from ORATORIO OLE has shown consistent and sustained treatment-associated benefit in multiple measures of CDP and a good safety profile over 6.5 years [47]. Mean percentage changes of brain T2-hyperintense $(p<0.001)$ and T1-hypointense $(p<0.001)$ LVs were lower in patients who initiated ocrelizumab early than in those initially receiving placebo from baseline to week 168 [47]. No difference in the rates of whole brain $(p=0.13)$ and cortical gray matter atrophy $(p=0.38)$ from baseline to week 144 was found between the two groups.

Some ongoing RCTs and observational studies are investigating additional aspects, including long-term effectiveness and safety of ocrelizumab and of treatment switch from natalizumab or rituximab to ocrelizumab [48].

\section{Ofatumumab}

Ofatumumab is the first fully human anti-CD20 monoclonal antibody, with a $20 \mathrm{mg}$ s.c. monthly dosing regimen (Fig. 2), which has been approved by FDA (August 2020) and EMA (March 2021) for the treatment of active relapsing MS forms.

A phase-II RCT evaluated 38 RRMS patients who received two i.v. infusions of ofatumumab 100, 300, or $700 \mathrm{mg}$ or placebo 2 weeks apart (Table 3) [49]. After 24 weeks, ofatumumab promoted an almost completed suppression of brain new/enlarging T2-hyperintense and Gdenhancing lesions (>99\%).

Another phase-II RCT, the MIRROR study, randomized 232 RRMS patients [50] into placebo, ofatumumab 3, 30 or $60 \mathrm{mg}$ every 12 weeks, or ofatumumab $60 \mathrm{mg}$ every 4 weeks. All patients were treated for 24 weeks and followed up until B-cell repletion. Overall, 26 RRMS patients had a relapse during the first 12 weeks, 11 (42\%) of whom during the first 4 weeks. Over 24 weeks, 17 (25\%) RRMS patients relapsed in the placebo group compared with three to ten RRMS patients (9-22\%) in the ofatumumab groups. Most patients $(79 \%)$ had unchanged EDSS scores at weeks 12 and 24 [50]. With all ofatumumab regimens, the mean cumulative number of Gd-enhancing lesions was reduced by $65 \%$ from baseline to week $12(p<0.001)$, with reductions $\geq 90 \%$ for each dose $\geq 30 \mathrm{mg}(p<0.002)$ [50].

Two recent phase-III RCTs (ASCLEPIOS I and II) in RRMS patients compared the efficacy and safety of ofatumumab (20 mg, s.c. administration every 4 weeks) (465 and 481 RRMS patients) with oral teriflunomide $14 \mathrm{mg}$ daily (462 and 474 patients) [3]. Ofatumumab groups showed a significant lower ARR compared with teriflunomide groups $(p<0.001)$. In pooled analysis, ofatumumab significantly 


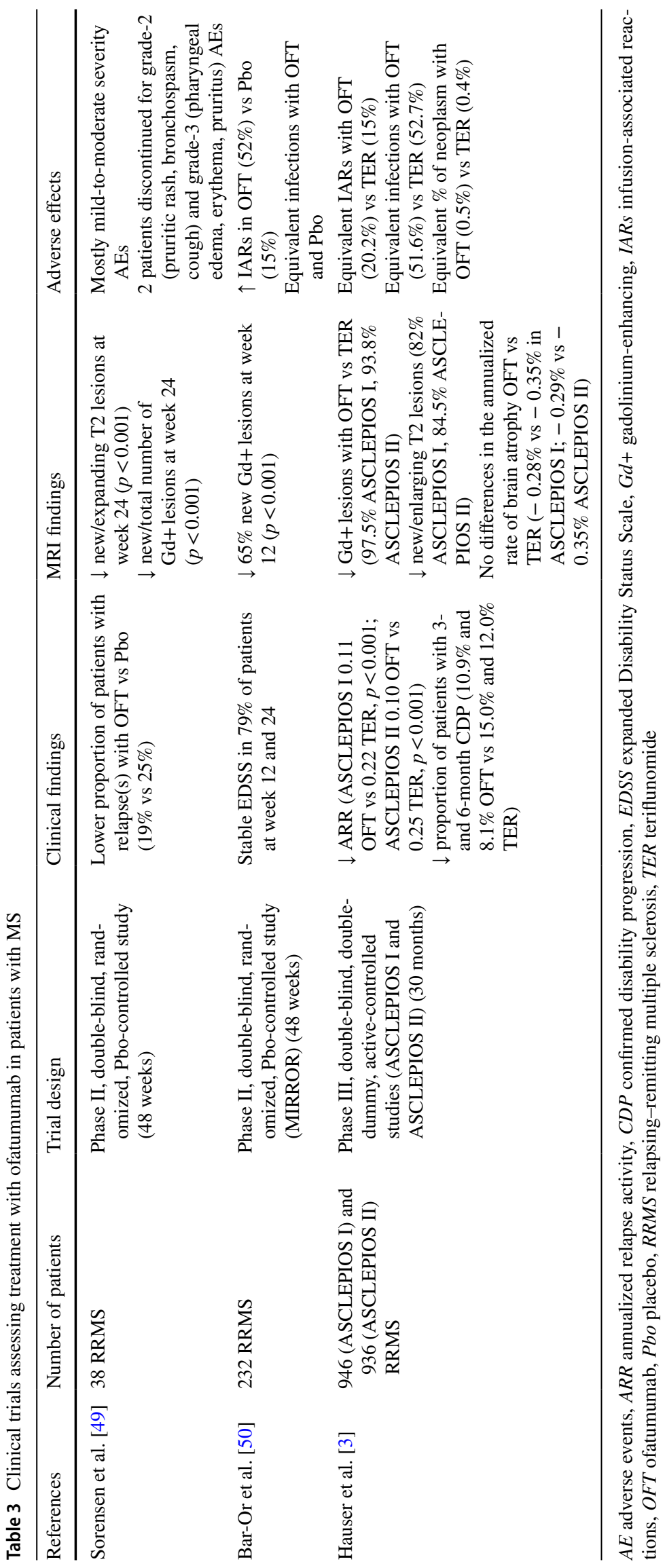


reduced the risk of 12 -week CDP by $34.4 \%$ and $32.5 \%$ at 3 and 6 months ( $p=0.002$ and $p=0.012)$, whereas percentages of patients with 24-week disability improvement were not significantly different between treatment groups $(p=0.09)$ (Table 3).

Ofatumumab promoted also a more effective suppression of MRI activity compared with teriflunomide, with a significant reduction of new/enlarging T2-hyperintense (ASCLEPIOS I $=82 \%$; ASCLEPIOS $\mathrm{II}=84.5 \%$ ) and $\mathrm{Gd}-$ enhancing lesions (ASCLEPIOS $\mathrm{I}=97.5 \%$; ASCLEPIOS $\mathrm{II}=93.8 \%$ ). The annualized brain atrophy rate did not differ significantly between the ofatumumab- and teriflunomide groups $(-0.28 \%$ vs $-0.35 \%$ in ASCLEPIOS I; $-0.29 \%$ vs $-0.35 \%$ ASCLEPIOS II).

\section{Safety and tolerability of anti-CD20 therapies}

\section{Infusion-associated adverse events}

Treatment infusion-associated reactions (IARs) are of mildto-moderate severity. The most common symptoms are fever, headache, rash, nausea, throat irritation, hypotension, and itching. There are no studies comparing the safety profile of different anti-CD20 therapies; evaluating IARs across studies is challenging given different premedication regimens [51].

In a phase-II RCT, IARs were disclosed in $78.3 \%$ of RRMS patients treated with rituximab compared with $40.0 \%$ in the placebo group [1].

In the OPERA I and II studies, IARs were reported in $34 \%$ of the RRMS patients treated with ocrelizumab compared with $10 \%$ of those treated with INF $\beta-1$ a or placebo, whereas the prevalence was $40 \%$ with ocrelizumab versus 26\% with placebo in PPMS from the ORATORIO trial [2]. In the OPERA I/II and ORATORIO OLE studies [42, 47], IARs incidence was consistent with past reports.

In the MIRROR study, a similar percentage of IARs was reported for ofatumumab (41-66\% according to the regimen used vs $15 \%$ for placebo) [50]. In ASCLEPIOS I/II, IARs occurred in $20.2 \%$ in the ofatumumab group and $15.0 \%$ in the teriflunomide group [3].

\section{Hypogammaglobulinemia}

Although CD20 is not expressed on plasmablasts and plasma cells (Fig. 2), anti-CD20-depleting therapies have been shown to reduce Ig levels. Rituximab has some impact on serum IgM and IgG levels [52], and hypogammaglobulinemia can be found during long-time treatment [53]. In RCTs, ocrelizumab reduced the total serum Ig levels to some extent with greatest impact on IgM [2]. However, there was no association between low IgM levels and serious infections. In the MIRROR study, only two out of 232 (1\%) RRMS patients treated with ofatumumab developed decreased $\operatorname{IgG}$ levels, leading to study termination [50]. In ASCLEPIOS I and II, no association was observed between a decrease in Ig levels and the incidence of serious/non-serious infections in ofatumumab-treated patients who experienced infections within 1 month prior and until 1 month after a reduction in Ig levels below the lower lymphocyte number [3].

\section{Infections and COVID-19 interaction}

Before starting treatment, the screening for latent infections should be performed. Reactivation of tuberculosis, hepatitis, and human immunodeficiency virus has been reported in patients treated with anti-CD20 therapies [54].

Although the incidence of infections in the placebo (71.4\%) and treated (69.7\%) groups in the first phase-II RCT of rituximab in RRMS was similar [1], rituximab was associated with an increased incidence of urinary tract infections and sinusitis.

In RCTs with ocrelizumab, the percentage of patients reporting any infection was $59.9 \%$ (vs $54.3 \%$ in patients treated with INF $\beta-1 \mathrm{a}$ ) in OPERA I, $60.2 \%$ (vs $52.5 \%$ in patients treated with IFNB-1a) in OPERA II and $71.4 \%$ in ORATORIO (vs $69.9 \%$ in the placebo group). A slightly increased incidence of upper respiratory tract infections was observed in patients treated with ocrelizumab compared with placebo or INF- $\beta$-1a [2]. No increased risk of serious infections was reported in any of these studies.

No cases of progressive multifocal leukoencephalopathy (PML) were reported in RCTs with ocrelizumab, whereas ten cases of PML (as of June 2021) have been described in post-marketing surveillance, of which eight were carry-over cases from prior DMTs [55].

According to data from the phase-II/III RCTs, ofatumumab was not associated with an increased risk of infection-related adverse events (AE) compared with placebo and teriflunomide $[3,50]$.

Recently, the COVID-19 pandemic raised some concerns about immunosuppression in MS, leading to treatment delay or cessation. Some publications have suggested that anti-CD20 therapies in a 6-month schedule (i.e., rituximab and ocrelizumab) may be associated with an increased risk of severe COVID-19 disease and need for hospitalization [56], not confirmed by a recent study [57]. MS patients appear to respond to SARS-CoV2 in a similar way to the general population and high disability or a progressive disease course represent the most relevant risk factors for a severe COVID-19 disease in MS. Moreover, innate immune response, and, probably, antiviral CD8 T-cell responses play a major role in eliminating the SARS-CoV2 before significant antibody responses have developed, thus B cells do not appear to be an absolute requirement 
for recovery. Duration of exposure might play a role, as suggested by the North American Registry, which disclosed an increased risk of hospitalization in patients treated with rituximab, but not in those treated with ocrelizumab [58].

\section{Malignancies}

Immunosuppressive drugs could influence immunological tumor surveillance; therefore, long-term data are required to exclude an increased rate of malignancies. In MS patients, rituximab was not associated with an increased neoplastic risk over the long term compared with the general population [59].

In the OPERA I and OPERA II trials, four patients (0.7\%) treated with ocrelizumab developed malignancies compared with two patients $(0.2 \%)$ treated with INF- $\beta-1 \mathrm{a}$ [2]. In the ORATORIO trial, 11 patients receiving ocrelizumab (2.3\%) developed malignancies (4 breast cancer) compared with two patients $(0.8 \%)$ in the placebo group [2]. The percentage of patients developing breast cancer in the ocrelizumab-treated group was similar to those expected from epidemiological studies and the incidence decreased during the extension studies [51].

In ASCLEPIOS I/II trials, no unexpected imbalance in the rates of malignancies was observed in ofatumumabtreated patients [3].

\section{Vaccination}

Patients should complete any required vaccinations at least 6 weeks prior to treatment initiation. Live attenuated or live vaccines are not recommended during treatment and until B-cell recovery, and at least 6 months after the last administration of rituximab [60].

A recent phase-IIIb RCT (VELOCE) [60] provided classII evidence that peripherally B-cell-depleted ocrelizumab recipients mounted humoral responses to clinically relevant vaccines and the neo-antigen, KLH, although attenuated. For non-live/inactivated vaccines, such as seasonal influenza vaccines, it is recommended to vaccinate patients treated with ocrelizumab since a protective humoral response can be expected, even if attenuated [60]. An expert consensus recently suggested that patients planned to receive ocrelizumab should be vaccinated at least 6 weeks before the first administration, whereas in those already receiving ocrelizumab, vaccinations should be administered at least 3 months after the last infusion [61].

\section{Therapies currently under investigation and future perspectives}

Few studies have investigated ublituximab, a third-generation glycol-engineered chimeric anti-CD20 antibody promoting B-cell depletion through ADCC (Table 4). In a phase-II study of 48 RRMS patients [62], ublituximab promoted a complete B-cell depletion (>99\%) within 4 weeks. The ARR was $0.07,93 \%$ of the patients were relapse-free at week 48 , and no patients demonstrated CDP. T2-hyperintense LV decreased by $8 \%$ at week 24 $(p=0.004)$ and $10 \%$ at week $48(p=0.016)$, whereas the mean number of $\mathrm{Gd}$-enhancing lesions was reduced from 3.8 at baseline to 0 at week $24(p=0.003)$ and maintained at week $48(p<0.001)$. The most common AEs were IARs that were all grade 1 or 2 ; no severe AEs were reported. No serious or opportunistic infections and no liver disease occurred. Ublituximab is currently being tested against teriflunomide in two fully enrolled phase-III studies (ULTIMATE I and II) in patients with RRMS (ClinicalTrials.gov identifier: NCT03277261 and NCT03277248).

Given the central role of B cells in MS pathogenesis, new therapeutic strategies directed against B-cell targets are currently under investigations (Table 4). CD19, a member of Ig superfamily, is involved in signal transduction following B-cell-receptor activation and represents one of the main regulator of B-cell activation and humoral immunity [63]. CD19 is more broadly expressed on cells of $\mathrm{B}$ lineage since, in contrast to $\mathrm{CD} 20$, it is also expressed on pro-B cells, plasmablasts and Ig-producing plasma cells (Fig. 2) [63]. Anti-CD19 therapies produce a more longlasting B-cell depletion and a marked decline in Ig concentrations [63].

Among the different anti-CD19 monoclonal antibodies, inebilizumab (MEDI-551) is a glycoengineered, afucosylated anti-CD19 antibody having high affinity to FcyRIIA and causing B-cell depletion through ADCC [64]. A 24-week phase-I RCT (ClinicalTrials.gov study identifier: NCT01585766) investigated pharmacological properties and safety of inebilizumab in RRMS patients compared with placebo [65]. Inebilizumab promoted a complete B-cell depletion with all doses ( 2 i.v. doses, days 1 and 15: 30, 100 or $600 \mathrm{mg}$; or single s.c. dose on day 1: 60 or $300 \mathrm{mg}$ ), with IAR occurring in seven out of 21 (33.3\%) RRMS patients and with upper respiratory tract and urinary tract infections, pyrexia and increased blood pressure as the most common AEs. At week 24, neither relapses nor median EDSS score changes occurred in RRMS patients receiving inebilizumab. Moreover, inebilizumab promoted trend in reductions in new/newly enlarging T2-hyperitense ( 0.4 vs 2.4 ) and Gdenhancing lesions ( 0.1 vs 1.3 ), with a higher proportion of patients free from new inflammatory activity (75\% vs $43 \%)$ [65].

Bruton's tyrosine kinase (BTK) is a cytoplasmic kinase expressed on cells of the hematopoietic lineage, except for $\mathrm{T}$ cells, natural killer (NK) cells and plasma cells, and contributes to signal transductions from B-cell receptor (BCR) to the PI3K, MAPK and NF-kB pathways, thus regulating B-cell 


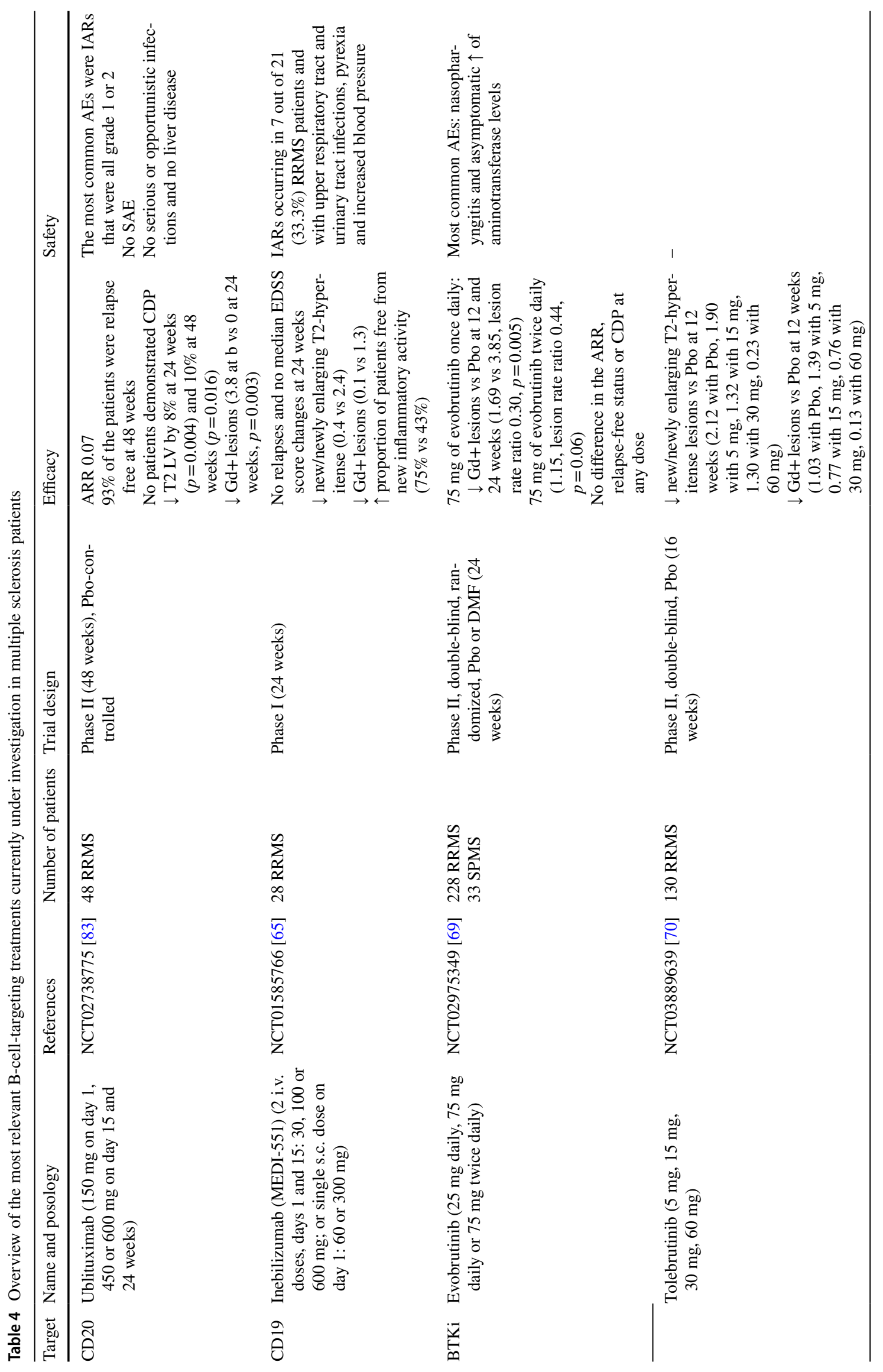




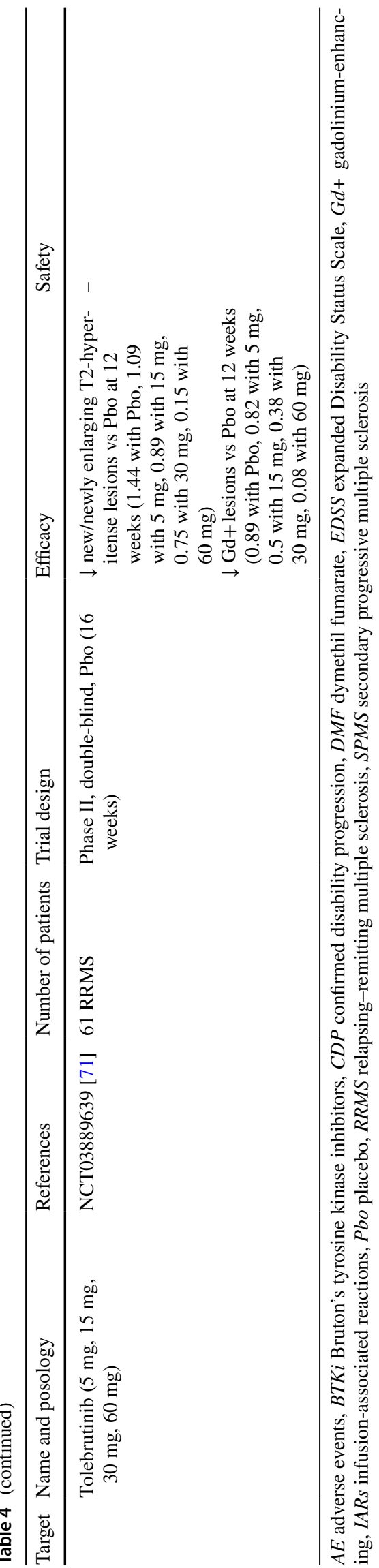

survival, activation, proliferation, and differentiation to plasma cells $[66,67]$.

Several BTK inhibitors have been proposed for the treatment of hematological malignancies and dysimmune disorders [66, 68]. A recent 24-week phase-II RCT (ClinicalTrials.gov study identifier: NCT02975349) [69] compared oral evobrutinib at different doses ( $25 \mathrm{mg}$ daily, $75 \mathrm{mg}$ daily or $75 \mathrm{mg}$ twice daily) with placebo or dimethyl fumarate in patients with RRMS or active SPMS. MS patients who received $75 \mathrm{mg}$ of evobrutinib once daily had significantly fewer Gd-enhancing lesions compared with placebo at weeks 12 through 24 (1.69 vs 3.85 , lesion rate ratio $0.30, p=0.005$ ), whereas only a trend for patients who received $75 \mathrm{mg}$ of evobrutinib twice daily was found $(1.15$, lesion rate ratio $0.44, p=0.06)$ [69]. No significant difference in the ARR, relapse-free status or disability progression at any dose occurred [69]. The most common AEs were nasopharyngitis and asymptomatic increase of aminotransferase levels.

In a 16-week phase-IIb study, 130 patients with RRMS were randomized to receive either placebo or tolebrutinib at different doses $(5,15,30$, and $60 \mathrm{mg})$ [70]. At week 12, patients treated with tolebrutinib had significantly lower mean number of new/enlarging T2-hyperintense lesions compared with placebo (1.90 with $5 \mathrm{mg}, 1.32$ with $15 \mathrm{mg}, 1.30$ with $30 \mathrm{mg}, 0.23$ with $60 \mathrm{mg}$ vs 2.12 with placebo). Tolebrutinib also reduced the mean number of Gd-enhancing lesions (1.39 with $5 \mathrm{mg}, 0.77$ with $15 \mathrm{mg}, 0.76$ with $30 \mathrm{mg}, 0.13$ with $60 \mathrm{mg}$ vs 1.03 with placebo).

Recently, in a subgroup analysis including 61 patients with highly active disease [71] (i.e., one relapse in the year prior to screening and one or more Gd-enhancing lesion on MRI within 6 months prior to screening or nine or more T2-hyperintense lesions at baseline, or two or more relapses in the year prior to screening), at week 12 , tolebrutinib reduced the mean number of new/enlarging T2-hyperintense lesions compared with placebo (1.09 with $5 \mathrm{mg}$, 0.89 with $15 \mathrm{mg}, 0.75$ with $30 \mathrm{mg}$, and 0.15 with $60 \mathrm{mg}$ vs 1.44 with placebo). Tolebrutinib also promoted a reduction in the mean number of new Gd-enhancing lesions compared with placebo $(0.82$ with $5 \mathrm{mg}$, 0.50 with $15 \mathrm{mg}, 0.38$ with $30 \mathrm{mg}$, and 0.08 with $60 \mathrm{mg}$ vs 0.89 ).

Several other BTK inhibitors are under investigation (see Ref. [66] for a comprehensive review), possibly representing a new therapeutic opportunity for MS patients in the near future although several aspects regarding their mechanism of action, efficacy and safety still need to be fully investigated. 


\section{Conclusions}

The introduction of anti-CD20 therapies in the MS scenario confirmed the central role of B cells in MS pathogenesis and established a new therapeutic approach for both relapsing and progressive MS patients.

In RRMS, currently approved anti-CD20 monoclonal antibodies (rituximab, ocrelizumab, and ofatumumab) consistently lead to a dramatic reduction of clinical relapses and MRI disease activity together with a significant limitation of disability worsening and brain atrophy progression.

Interestingly, ocrelizumab has been the first effective DMT in delaying disability progression in PPMS. However, efficacy and benefits in PPMS appear partial and more limited compared with those observed in RRMS. These findings suggest that anti-CD20 therapies exert a strong anti-inflammatory activity and that their beneficial neuroprotective effects could be mainly secondary to the prevention of further inflammatory disease activity. The more limited effect in PPMS could be also due to an inefficient depletion of B cells within a CNS-compartmentalized inflammation, possibly due to a limited permeability of anti-CD20 monoclonal antibodies across the blood-brain barrier. This aspect should be better investigated in future studies which should include reliable clinical, laboratory and MRI biomarkers to identify and monitor MS progression.

Data from RCTs, their OLE and from observational studies suggest that anti-CD20 therapies have a favorable shortand medium-term safety profile, with IARs, upper respiratory tract and urinary infections being the most common side effects, although the risk of malignancies should be carefully monitored over long-term.

Several aspects regarding treatment with anti-CD20 therapies deserve further investigations.

Future studies should define how to optimize anti-CD20 therapy administration regimens in terms of dosing, timing and duration of the treatment. Finally, post-marketing and observational studies should be conducted to shed light on beneficial effects and risks over longer term and to better explore the risk of infections and malignancies, especially in older MS patients.

\section{Acknowledgements None.}

Author contributions MM: drafting/revising the manuscript, study concept, acquisition and interpretation of the data; PP: drafting/revising the manuscript, study concept, acquisition and interpretation of the data; MF: drafting/revising the manuscript, study concept, acquisition and interpretation of the data; MAR: drafting/revising the manuscript, study concept, acquisition and interpretation of the data.

Funding None.

\section{Declarations}

Conflicts of interest M. Margoni reports grants and personal fees from Sanofi Genzyme, Merck Serono, Novartis and Almirall. She was awarded a MAGNIMS-ECTRIMS fellowship in 2020. P. Preziosa received speaker honoraria from Biogen Idec, Novartis, Merck Serono and ExceMED. He is supported by a senior research fellowship FISM-Fondazione Italiana Sclerosi Multipla—cod. 2019/BS/009 and financed or co-financed with the ' 5 per mille' public funding. M. Filippi is Editor-in-Chief of the Journal of Neurology and Associate Editor of Radiology, Human Brain Mapping and Neurological Sciences, received compensation for consulting services and/or speaking activities from Almiral, Alexion, Bayer, Biogen, Celgene, Eli Lilly, Genzyme, Merck-Serono, Novartis, Roche, Sanofi, Takeda, and Teva Pharmaceutical Industries, and receives research support from Biogen Idec, Merck-Serono, Novartis, Roche, Teva Pharmaceutical Industries, Italian Ministry of Health, Fondazione Italiana Sclerosi Multipla, and ARiSLA (Fondazione Italiana di Ricerca per la SLA). M.A. Rocca received speaker honoraria from Bayer, Biogen, Bristol Myers Squibb, Celgene, Genzyme, Merck Serono, Novartis, Roche, and Teva, and receives research support from the MS Society of Canada and Fondazione Italiana Sclerosi Multipla.

\section{References}

1. Hauser SL, Waubant E, Arnold DL, Vollmer T, Antel J, Fox RJ, Bar-Or A, Panzara M, Sarkar N, Agarwal S, Langer-Gould A, Smith CH, HT Group (2008) B-cell depletion with rituximab in relapsing-remitting multiple sclerosis. N Engl J Med 358(7):676688. https://doi.org/10.1056/NEJMoa0706383

2. Montalban X, Hauser SL, Kappos L, Arnold DL, Bar-Or A, Comi G, de Seze J, Giovannoni G, Hartung HP, Hemmer B, Lublin F, Rammohan KW, Selmaj K, Traboulsee A, Sauter A, Masterman D, Fontoura P, Belachew S, Garren H, Mairon N, Chin P, Wolinsky JS, OC Investigators (2017) Ocrelizumab versus placebo in primary progressive multiple sclerosis. N Engl J Med 376(3):209-220. https://doi.org/10.1056/NEJMoa1606468

3. Hauser SL, Bar-Or A, Cohen JA, Comi G, Correale J, Coyle PK, Cross AH, de Seze J, Leppert D, Montalban X, Selmaj K, Wiendl H, Kerloeguen C, Willi R, Li B, Kakarieka A, Tomic D, Goodyear A, Pingili R, Haring DA, Ramanathan K, Merschhemke M, Kappos L, Asclepios I, AIT Groups (2020) Ofatumumab versus teriflunomide in multiple sclerosis. N Engl J Med 383(6):546-557. https://doi.org/10.1056/NEJMoa1917246

4. Baecher-Allan C, Kaskow BJ, Weiner HL (2018) Multiple sclerosis: mechanisms and immunotherapy. Neuron 97(4):742-768. https://doi.org/10.1016/j.neuron.2018.01.021

5. Dendrou CA, Fugger L, Friese MA (2015) Immunopathology of multiple sclerosis. Nat Rev Immunol 15(9):545-558. https://doi. org/10.1038/nri3871

6. Li R, Patterson KR, Bar-Or A (2018) Reassessing B cell contributions in multiple sclerosis. Nat Immunol 19(7):696-707. https:// doi.org/10.1038/s41590-018-0135-x

7. Hauser SL, Bar-Or A, Comi G, Giovannoni G, Hartung HP, Hemmer B, Lublin F, Montalban X, Rammohan KW, Selmaj K, Traboulsee A, Wolinsky JS, Arnold DL, Klingelschmitt G, Masterman D, Fontoura P, Belachew S, Chin P, Mairon N, Garren H, Kappos L, Opera I, OIC Investigators (2017) Ocrelizumab versus interferon beta-1a in relapsing multiple sclerosis. N Engl J Med 376(3):221-234. https://doi.org/10.1056/NEJMoa1601277

8. Storch MK, Piddlesden S, Haltia M, Iivanainen M, Morgan P, Lassmann H (1998) Multiple sclerosis: in situ evidence for 
antibody- and complement-mediated demyelination. Ann Neurol 43(4):465-471. https://doi.org/10.1002/ana.410430409

9. Genain CP, Cannella B, Hauser SL, Raine CS (1999) Identification of autoantibodies associated with myelin damage in multiple sclerosis. Nat Med 5(2):170-175. https://doi.org/10.1038/5532

10. Lucchinetti C, Bruck W, Parisi J, Scheithauer B, Rodriguez M, Lassmann H (2000) Heterogeneity of multiple sclerosis lesions: implications for the pathogenesis of demyelination. Ann Neurol 47(6):707-717. https://doi.org/10.1002/1531-8249(200006)47:6\% 3c707::aid-ana3\%3e3.0.co;2-q

11. Obermeier B, Mentele R, Malotka J, Kellermann J, Kumpfel T, Wekerle H, Lottspeich F, Hohlfeld R, Dornmair K (2008) Matching of oligoclonal immunoglobulin transcriptomes and proteomes of cerebrospinal fluid in multiple sclerosis. Nat Med 14(6):688693. https://doi.org/10.1038/nm1714

12. Cepok S, Rosche B, Grummel V, Vogel F, Zhou D, Sayn J, Sommer N, Hartung HP, Hemmer B (2005) Short-lived plasma blasts are the main $\mathrm{B}$ cell effector subset during the course of multiple sclerosis. Brain 128(Pt 7):1667-1676. https://doi.org/10.1093/ brain/awh486

13. Bar-Or A (2008) The immunology of multiple sclerosis. Semin Neurol 28(1):29-45. https://doi.org/10.1055/s-2007-1019124

14. Kuhle J, Pohl C, Mehling M, Edan G, Freedman MS, Hartung HP, Polman CH, Miller DH, Montalban X, Barkhof F, Bauer L, Dahms S, Lindberg R, Kappos L, Sandbrink R (2007) Lack of association between antimyelin antibodies and progression to multiple sclerosis. N Engl J Med 356(4):371-378. https://doi.org/10. 1056/NEJMoa063602

15. Brickshawana A, Hinson SR, Romero MF, Lucchinetti CF, Guo Y, Buttmann M, McKeon A, Pittock SJ, Chang MH, Chen AP, Kryzer TJ, Fryer JP, Jenkins SM, Cabre P, Lennon VA (2014) Investigation of the KIR4.1 potassium channel as a putative antigen in patients with multiple sclerosis: a comparative study. Lancet Neurol 13(8):795-806. https://doi.org/10.1016/S1474-4422(14) 70141-3

16. Srivastava R, Aslam M, Kalluri SR, Schirmer L, Buck D, Tackenberg B, Rothhammer V, Chan A, Gold R, Berthele A, Bennett JL, Korn T, Hemmer B (2012) Potassium channel KIR4.1 as an immune target in multiple sclerosis. N Engl J Med 367(2):115123. https://doi.org/10.1056/NEJMoa1110740

17. Rodriguez-Pinto D (2005) B cells as antigen presenting cells. Cell Immunol 238(2):67-75. https://doi.org/10.1016/j.cellimm.2006. 02.005

18. Bar-Or A, Fawaz L, Fan B, Darlington PJ, Rieger A, Ghorayeb C, Calabresi PA, Waubant E, Hauser SL, Zhang J, Smith CH (2010) Abnormal B-cell cytokine responses a trigger of T-cell-mediated disease in MS? Ann Neurol 67(4):452-461. https://doi.org/10. 1002/ana.21939

19. Li R, Rezk A, Miyazaki Y, Hilgenberg E, Touil H, Shen P, Moore CS, Michel L, Althekair F, Rajasekharan S, Gommerman JL, Prat A, Fillatreau S, Bar-Or A, Canadian BciMST (2015) Proinflammatory GM-CSF-producing B cells in multiple sclerosis and B cell depletion therapy. Sci Transl Med 7(310):310ra166. https:// doi.org/10.1126/scitranslmed.aab4176

20. Duddy M, Niino M, Adatia F, Hebert S, Freedman M, Atkins H, Kim HJ, Bar-Or A (2007) Distinct effector cytokine profiles of memory and naive human B cell subsets and implication in multiple sclerosis. J Immunol 178(10):6092-6099. https://doi.org/10. 4049/jimmunol.178.10.6092

21. Barr TA, Shen P, Brown S, Lampropoulou V, Roch T, Lawrie S, Fan B, O'Connor RA, Anderton SM, Bar-Or A, Fillatreau S, Gray D (2012) B cell depletion therapy ameliorates autoimmune disease through ablation of IL-6-producing B cells. J Exp Med 209(5):1001-1010. https://doi.org/10.1084/jem.20111675

22. Li R, Rezk A, Healy LM, Muirhead G, Prat A, Gommerman JL, Bar-Or A, MCBciM Team (2015) Cytokine-defined B cell responses as therapeutic targets in multiple sclerosis. Front Immunol 6:626. https://doi.org/10.3389/fimmu.2015.00626

23. Frischer JM, Bramow S, Dal-Bianco A, Lucchinetti CF, Rauschka H, Schmidbauer M, Laursen H, Sorensen PS, Lassmann H (2009) The relation between inflammation and neurodegeneration in multiple sclerosis brains. Brain 132(Pt 5):1175-1189. https://doi.org/ 10.1093/brain/awp070

24. Machado-Santos J, Saji E, Troscher AR, Paunovic M, Liblau R, Gabriely G, Bien CG, Bauer J, Lassmann H (2018) The compartmentalized inflammatory response in the multiple sclerosis brain is composed of tissue-resident CD8+ T lymphocytes and B cells. Brain 141(7):2066-2082. https://doi.org/10.1093/brain/awy151

25. Magliozzi R, Howell O, Vora A, Serafini B, Nicholas R, Puopolo M, Reynolds R, Aloisi F (2007) Meningeal B-cell follicles in secondary progressive multiple sclerosis associate with early onset of disease and severe cortical pathology. Brain 130(Pt 4):1089-1104. https://doi.org/10.1093/brain/awm038

26. Magliozzi R, Howell OW, Nicholas R, Cruciani C, Castellaro M, Romualdi C, Rossi S, Pitteri M, Benedetti MD, Gajofatto A, Pizzini FB, Montemezzi S, Rasia S, Capra R, Bertoldo A, Facchiano F, Monaco S, Reynolds R, Calabrese M (2018) Inflammatory intrathecal profiles and cortical damage in multiple sclerosis. Ann Neurol 83(4):739-755. https://doi.org/10.1002/ana.25197

27. Magliozzi R, Serafini B, Rosicarelli B, Chiappetta G, Veroni C, Reynolds R, Aloisi F (2013) B-cell enrichment and Epstein-Barr virus infection in inflammatory cortical lesions in secondary progressive multiple sclerosis. J Neuropathol Exp Neurol 72(1):2941. https://doi.org/10.1097/NEN.0b013e31827bfc62

28. Meinl E, Krumbholz M, Hohlfeld R (2006) B lineage cells in the inflammatory central nervous system environment: migration, maintenance, local antibody production, and therapeutic modulation. Ann Neurol 59(6):880-892. https://doi.org/10.1002/ana. 20890

29. Touil H, Kobert A, Lebeurrier N, Rieger A, Saikali P, Lambert C, Fawaz L, Moore CS, Prat A, Gommerman J, Antel JP, Itoyama Y, Nakashima I, Bar-Or A, Canadian BCTiMS (2018) Human central nervous system astrocytes support survival and activation of B cells: implications for MS pathogenesis. J Neuroinflammation 15(1):114. https://doi.org/10.1186/s12974-018-1136-2

30. Mahad DH, Trapp BD, Lassmann H (2015) Pathological mechanisms in progressive multiple sclerosis. Lancet Neurol 14(2):183193. https://doi.org/10.1016/S1474-4422(14)70256-X

31. Magliozzi R, Howell OW, Reeves C, Roncaroli F, Nicholas R, Serafini B, Aloisi F, Reynolds R (2010) A Gradient of neuronal loss and meningeal inflammation in multiple sclerosis. Ann Neurol 68(4):477-493. https://doi.org/10.1002/ana.22230

32. Lucchinetti CF, Popescu BF, Bunyan RF, Moll NM, Roemer SF, Lassmann H, Bruck W, Parisi JE, Scheithauer BW, Giannini C, Weigand SD, Mandrekar J, Ransohoff RM (2011) Inflammatory cortical demyelination in early multiple sclerosis. N Engl J Med 365(23):2188-2197. https://doi.org/10.1056/NEJMoa1 100648

33. Meyer S, Evers M, Jansen JHM, Buijs J, Broek B, Reitsma SE, Moerer P, Amini M, Kretschmer A, Ten Broeke T, den Hartog MT, Rijke M, Klein C, Valerius T, Boross P, Leusen JHW (2018) New insights in type I and II CD20 antibody mechanisms-ofaction with a panel of novel CD20 antibodies. Br J Haematol 180(6):808-820. https://doi.org/10.1111/bjh.15132

34. Montalvao F, Garcia Z, Celli S, Breart B, Deguine J, Van Rooijen N, Bousso P (2013) The mechanism of anti-CD20-mediated $\mathrm{B}$ cell depletion revealed by intravital imaging. J Clin Invest 123(12):5098-5103. https://doi.org/10.1172/JCI70972

35. Cencioni MT, Mattoscio M, Magliozzi R, Bar-Or A, Muraro PA (2021) B cells in multiple sclerosis-from targeted depletion to immune reconstitution therapies. Nat Rev Neurol. https://doi.org/ $10.1038 / \mathrm{s} 41582-021-00498-5$ 
36. Yang CS, Yang L, Li T, Zhang DQ, Jin WN, Li MS, Su N, Zhangning N, Liu Q, Shao ZH, Yu C, Shi FD (2013) Responsiveness to reduced dosage of rituximab in Chinese patients with neuromyelitis optica. Neurology 81(8):710-713. https://doi.org/10.1212/ WNL.0b013e3182a1aac7

37. Hawker K, O'Connor P, Freedman MS, Calabresi PA, Antel J, Simon J, Hauser S, Waubant E, Vollmer T, Panitch H, Zhang J, Chin P, Smith CH, OT Group (2009) Rituximab in patients with primary progressive multiple sclerosis: results of a randomized double-blind placebo-controlled multicenter trial. Ann Neurol 66(4):460-471. https://doi.org/10.1002/ana.21867

38. Ingle GT, Sastre-Garriga J, Miller DH, Thompson AJ (2005) Is inflammation important in early PPMS? A longitudinal MRI study. J Neurol Neurosurg Psychiatry 76(9):1255-1258. https:// doi.org/10.1136/jnnp.2004.036590

39. Bhargava P, Wicken C, Smith MD, Strowd RE, Cortese I, Reich DS, Calabresi PA, Mowry EM (2019) Trial of intrathecal rituximab in progressive multiple sclerosis patients with evidence of leptomeningeal contrast enhancement. Mult Scler Relat Disord 30:136-140. https://doi.org/10.1016/j.msard.2019.02.013

40. Kappos L, Li D, Calabresi PA, O’Connor P, Bar-Or A, Barkhof F, Yin M, Leppert D, Glanzman R, Tinbergen J, Hauser SL (2011) Ocrelizumab in relapsing-remitting multiple sclerosis: a phase 2, randomised, placebo-controlled, multicentre trial. Lancet 378(9805):1779-1787. https://doi.org/10.1016/S01406736(11)61649-8

41. Baker D, Pryce G, James LK, Marta M, Schmierer K (2020) The ocrelizumab phase II extension trial suggests the potential to improve the risk: benefit balance in multiple sclerosis. Mult Scler Relat Disord 44:102279. https://doi.org/10.1016/j.msard. 2020.102279

42. Hauser SL, Kappos L, Arnold DL, Bar-Or A, Brochet B, Naismith RT, Traboulsee A, Wolinsky JS, Belachew S, Koendgen H, Levesque V, Manfrini M, Model F, Hubeaux S, Mehta L, Montalban X (2020) Five years of ocrelizumab in relapsing multiple sclerosis: OPERA studies open-label extension. Neurology 95(13):e1854-e1867. https://doi.org/10.1212/WNL. 0000000000010376

43. Havrdova E, Arnold DL, Bar-Or A, Comi G, Hartung HP, Kappos L, Lublin F, Selmaj K, Traboulsee A, Belachew S, Bennett I, Buffels R, Garren H, Han J, Julian L, Napieralski J, Hauser SL, Giovannoni G (2018) No evidence of disease activity (NEDA) analysis by epochs in patients with relapsing multiple sclerosis treated with ocrelizumab vs interferon beta-1a. Mult Scler J Exp Transl Clin 4(1):2055217318760642. https://doi. org/10.1177/2055217318760642

44. Hartung HP, Berger T, Bermel R, Brochet B, Holmøy T, Karabudak R, Killestein J, Nos C, Patti F, Ross AP, Vollmer T, Wuerfel J, Buffels R, Kuenzel T, Freedman M (2020) Ocrelizumab phase IIIb efficacy: 1-year NEDA rates (with MRI rebaselining) from the ENSAMBLE study in early-stage relapsing-remitting MS patients. In: ECTRIMS, vol S3, pp 225-659, Poster P0220. https://library.msvirtual2020.org/. Accessed 5 Jul 2021

45. Wiendl H, Comi G, Oreja-Guevara C, Van Wijmeersch BAS, Buffels RJW, Kadner R, Kuenzel T, Vermersch P (2020) Ocrelizumab phase IIIb efficacy from CASTING: 2-year NEDA (MRI re-baselined) subgroup rates in RRMS patients with a suboptimal response to prior DMTs. In: ECTRIMS, 2020, vol S3, pp 224659, Poster P0219. https://library.msvirtual2020.org/. Accessed 5 Jul 2021

46. Turner B, Cree BAC, Kappos L, Montalban X, Papeix C, Wolinsky JS, Buffels R, Fiore D, Garren H, Han J, Hauser SL (2019) Ocrelizumab efficacy in subgroups of patients with relapsing multiple sclerosis. J Neurol 266(5):1182-1193. https://doi.org/ 10.1007/s00415-019-09248-6
47. Wolinsky JS, Arnold DL, Brochet B, Hartung HP, Montalban X, Naismith RT, Manfrini M, Overell J, Koendgen H, Sauter A, Bennett I, Hubeaux S, Kappos L, Hauser SL (2020) Long-term follow-up from the ORATORIO trial of ocrelizumab for primary progressive multiple sclerosis: a post-hoc analysis from the ongoing open-label extension of the randomised, placebo-controlled, phase 3 trial. Lancet Neurol 19(12):998-1009. https://doi.org/10. 1016/S1474-4422(20)30342-2

48. Mancinelli CR, Scarpazza C, Cordioli C, De Rossi N, Rasia S, Turrini MV, Capra R (2021) Switching to ocrelizumab in RRMS patients at risk of PML previously treated with extended interval dosing of natalizumab. Mult Scler 27(5):790-794. https://doi.org/ 10.1177/1352458520946017

49. Sorensen PS, Lisby S, Grove R, Derosier F, Shackelford S, Havrdova E, Drulovic J, Filippi M (2014) Safety and efficacy of ofatumumab in relapsing-remitting multiple sclerosis: a phase 2 study. Neurology 82(7):573-581. https://doi.org/10.1212/WNL.00000 00000000125

50. Bar-Or A, Grove RA, Austin DJ, Tolson JM, VanMeter SA, Lewis EW, Derosier FJ, Lopez MC, Kavanagh ST, Miller AE, Sorensen PS (2018) Subcutaneous ofatumumab in patients with relapsingremitting multiple sclerosis: the MIRROR Study. Neurology 90(20):e1805-e1814. https://doi.org/10.1212/WNL.0000000000 005516

51. Gelfand JM, Cree BAC, Hauser SL (2017) Ocrelizumab and other $\mathrm{CD} 20(+)$ B-cell-depleting therapies in multiple sclerosis. Neurotherapeutics 14(4):835-841. https://doi.org/10.1007/ s13311-017-0557-4

52. Salzer J, Svenningsson R, Alping P, Novakova L, Bjorck A, Fink $\mathrm{K}$, Islam-Jakobsson P, Malmestrom C, Axelsson M, Vagberg M, Sundstrom P, Lycke J, Piehl F, Svenningsson A (2016) Rituximab in multiple sclerosis: a retrospective observational study on safety and efficacy. Neurology 87(20):2074-2081. https://doi.org/ 10.1212/WNL.0000000000003331

53. Ineichen BV, Moridi T, Granberg T, Piehl F (2020) Rituximab treatment for multiple sclerosis. Mult Scler 26(2):137-152. https://doi.org/10.1177/1352458519858604

54. Mok CC (2013) Rituximab for the treatment of rheumatoid arthritis: an update. Drug Des Dev Ther 8:87-100. https://doi.org/10. 2147/DDDT.S41645

55. Patel A, Sul J, Gordon ML, Steinklein J, Sanguinetti S, Pramanik B, Purohit D, Haroutunian V, Williamson A, Koralnik I, Harel A (2021) Progressive multifocal leukoencephalopathy in a patient with progressive multiple sclerosis treated with ocrelizumab monotherapy. JAMA Neurol. https://doi.org/10.1001/jamaneurol.2021. 0627

56. Sormani MP, De Rossi N, Schiavetti I, Carmisciano L, Cordioli C, Moiola L, Radaelli M, Immovilli P, Capobianco M, Trojano M, Zaratin P, Tedeschi G, Comi G, Battaglia MA, Patti F, Salvetti M, Musc-19 Study Group (2021) Disease-modifying therapies and coronavirus disease 2019 severity in multiple sclerosis. Ann Neurol 89(4):780-789. https://doi.org/10.1002/ana.26028

57. Reder AT, Centonze D, Naylor ML, Nagpal A, Rajbhandari R, Altincatal A, Kim M, Berdofe A, Radhakrishnan M, Jung E, Sandrock AW, Smirnakis K, Popescu C, de Moor C (2021) COVID19 in patients with multiple sclerosis: associations with diseasemodifying therapies. CNS Drugs 35(3):317-330. https://doi.org/ 10.1007/s40263-021-00804-1

58. Salter A, Fox RJ, Newsome SD, Halper J, Li DKB, Kanellis P, Costello K, Bebo B, Rammohan K, Cutter GR, Cross AH (2021) Outcomes and risk factors associated with SARS-CoV-2 infection in a north American registry of patients with multiple sclerosis. JAMA Neurol. https://doi.org/10.1001/jamaneurol.2021.0688

59. Alping P, Askling J, Burman J, Fink K, Fogdell-Hahn A, Gunnarsson M, Hillert J, Langer-Gould A, Lycke J, Nilsson P, Salzer J, Svenningsson A, Vrethem M, Olsson T, Piehl F, Frisell T (2020) 
Cancer risk for fingolimod, natalizumab, and rituximab in multiple sclerosis patients. Ann Neurol 87(5):688-699. https://doi.org/ 10.1002/ana.25701

60. Bar-Or A, Calkwood JC, Chognot C, Evershed J, Fox EJ, Herman A, Manfrini M, McNamara J, Robertson DS, Stokmaier D, Wendt JK, Winthrop KL, Traboulsee A (2020) Effect of ocrelizumab on vaccine responses in patients with multiple sclerosis: the VELOCE Study. Neurology 95(14):e1999-e2008. https://doi. org/10.1212/WNL.0000000000010380

61. Centonze D, Rocca MA, Gasperini C, Kappos L, Hartung HP, Magyari M, Oreja-Guevara C, Trojano M, Wiendl H, Filippi M (2021) Disease-modifying therapies and SARS-CoV-2 vaccination in multiple sclerosis: an expert consensus. J Neurol. https:// doi.org/10.1007/s00415-021-10545-2

62. Fox E, Lovett-Racke AE, Gormley M, Liu Y, Petracca M, Cocozza S, Shubin R, Wray S, Weiss MS, Bosco JA, Power SA, Mok K, Inglese $M$ (2020) A phase 2 multicenter study of ublituximab, a novel glycoengineered anti-CD20 monoclonal antibody, in patients with relapsing forms of multiple sclerosis. Mult Scler. https://doi.org/10.1177/1352458520918375

63. Tedder TF (2009) CD19: a promising B cell target for rheumatoid arthritis. Nat Rev Rheumatol 5(10):572-577. https://doi.org/10. 1038/nrrheum.2009.184

64. Chen D, Gallagher S, Monson NL, Herbst R, Wang Y (2016) Inebilizumab, a B cell-depleting anti-CD19 antibody for the treatment of autoimmune neurological diseases: insights from preclinical studies. J Clin Med. https://doi.org/10.3390/jcm5120107

65. Agius MA, Klodowska-Duda G, Maciejowski M, Potemkowski A, Li J, Patra K, Wesley J, Madani S, Barron G, Katz E, Flor A (2019) Safety and tolerability of inebilizumab (MEDI-551), an anti-CD19 monoclonal antibody, in patients with relapsing forms of multiple sclerosis: results from a phase 1 randomised, placebocontrolled, escalating intravenous and subcutaneous dose study. Mult Scler 25(2):235-245. https://doi.org/10.1177/1352458517 740641

66. Contentti EC, Correale J (2020) Bruton's tyrosine kinase inhibitors: a promising emerging treatment option for multiple sclerosis. Expert Opin Emerg Drugs 25(4):377-381. https://doi.org/10. 1080/14728214.2020.1822817

67. Torke S, Weber MS (2020) Inhibition of Bruton s tyrosine kinase as a novel therapeutic approach in multiple sclerosis. Expert Opin Investig Drugs 29(10):1143-1150. https://doi.org/10.1080/13543 784.2020.1807934

68. Liang C, Tian D, Ren X, Ding S, Jia M, Xin M, Thareja S (2018) The development of Bruton's tyrosine kinase (BTK) inhibitors from 2012 to 2017: a mini-review. Eur J Med Chem 151:315-326. https://doi.org/10.1016/j.ejmech.2018.03.062

69. Montalban X, Arnold DL, Weber MS, Staikov I, Piasecka-Stryczynska K, Willmer J, Martin EC, Dangond F, Syed S, Wolinsky JS, Evobrutinib Phase 2 Study Group (2019) Placebo-controlled trial of an oral BTK inhibitor in multiple sclerosis. N Engl J Med 380(25):2406-2417. https://doi.org/10.1056/NEJMoa1901981

70. Reich DS, Honeycutt WD, Laganke C, Laplaud D-A, Montalban X, Robertson D, Uitdehaag BMJ, Wray S, Wynn D, Matta A, Turner T, Wallstrom E, Zhang X, Traboulsee A (2020) Efficacy and safety outcomes in patients with relapsing forms of MS treated with the CNS-penetrating BTK inhibitor SAR442168: results from the phase $2 b$ trial. Eur J Neurol 27(Suppl. 1):1-102 (O4010)

71. Syed S, Yonkers N, LaGanke C, Honeycutt WD, Traboulsee A, Wynn D, Wray S, Wallstroem E, Dukovic D, Turner T (2021) Efficacy and safety of tolebrutinib in patients with highly active relapsing MS: subgroup analysis of the phase 2b study (2260). Neurology 96(15 Supplement):2260

72. Bar-Or A, Calabresi PA, Arnold D, Markowitz C, Shafer S, Kasper LH, Waubant E, Gazda S, Fox RJ, Panzara M, Sarkar N,
Agarwal S, Smith CH (2008) Rituximab in relapsing-remitting multiple sclerosis: a 72-week, open-label, phase I trial. Ann Neurol 63(3):395-400. https://doi.org/10.1002/ana.21363

73. Naismith RT, Piccio L, Lyons JA, Lauber J, Tutlam NT, Parks BJ, Trinkaus K, Song SK, Cross AH (2010) Rituximab add-on therapy for breakthrough relapsing multiple sclerosis: a 52-week phase II trial. Neurology 74(23):1860-1867. https://doi.org/10. 1212/WNL.0b013e3181e24373

74. Alping P, Frisell T, Novakova L, Islam-Jakobsson P, Salzer J, Bjorck A, Axelsson M, Malmestrom C, Fink K, Lycke J, Svenningsson A, Piehl F (2016) Rituximab versus fingolimod after natalizumab in multiple sclerosis patients. Ann Neurol 79(6):950 958. https://doi.org/10.1002/ana.24651

75. de Flon P, Gunnarsson M, Laurell K, Soderstrom L, Birgander R, Lindqvist T, Krauss W, Dring A, Bergman J, Sundstrom P, Svenningsson A (2016) Reduced inflammation in relapsing-remitting multiple sclerosis after therapy switch to rituximab. Neurology 87(2):141-147. https://doi.org/10.1212/WNL.0000000000002832

76. Alcala C, Gascon F, Perez-Miralles F, Gil-Perotin S, Navarre A, Bosca I, Coret F, Casanova B (2018) Efficacy and safety of rituximab in relapsing and progressive multiple sclerosis: a hospitalbased study. J Neurol 265(7):1690-1697. https://doi.org/10.1007/ s00415-018-8899-3

77. Durozard P, Maarouf A, Boutiere C, Ruet A, Brochet B, Vukusic S, Carra-Dalliere C, Labauge P, Mathey G, Debouverie M, Papeix C, Maillart E, Lubetzki C, Bensa C, Gout O, Giannesini C, Stankoff B, Ciron J, Brassat D, Pelletier J, Rico Lamy A, Audoin B (2019) Efficacy of rituximab in refractory RRMS. Mult Scler 25(6):828-836. https://doi.org/10.1177/1352458518772748

78. Granqvist M, Boremalm M, Poorghobad A, Svenningsson A, Salzer J, Frisell T, Piehl F (2018) Comparative effectiveness of rituximab and other initial treatment choices for multiple sclerosis. JAMA Neurol 75(3):320-327. https://doi.org/10.1001/jamaneurol. 2017.4011

79. Yamout BI, El-Ayoubi NK, Nicolas J, El Kouzi Y, Khoury SJ, Zeineddine MM (2018) Safety and efficacy of rituximab in multiple sclerosis: a retrospective observational study. J Immunol Res 2018:9084759. https://doi.org/10.1155/2018/9084759

80. Honce JM, Nair KV, Sillau S, Valdez B, Miravalle A, Alvarez E, Schreiner T, Corboy JR, Vollmer TL (2019) Rituximab vs placebo induction prior to glatiramer acetate monotherapy in multiple sclerosis. Neurology 92(7):e723-e732. https://doi.org/10.1212/WNL. 0000000000006916

81. Zecca C, Bovis F, Novi G, Capobianco M, Lanzillo R, Frau J, Repice AM, Hakiki B, Realmuto S, Bonavita S, Curti E, Brambilla L, Mataluni G, Cavalla P, Di Sapio A, Signoriello E, Barone S, Maniscalco GT, Maietta I, Maraffi I, Boffa G, Malucchi S, Nozzolillo A, Coghe G, Mechi C, Salemi G, Gallo A, Sacco R, Cellerino M, Malentacchi M, De Angelis M, Lorefice L, Magnani E, Prestipino E, Sperli F, Morra VB, Fenu G, Barilaro A, Abbadessa G, Signori A, Granella F, Amato MP, Uccelli A, Gobbi C, Sormani MP (2020) Treatment of multiple sclerosis with rituximab: a multicentric Italian-Swiss experience. Mult Scler 26(12):1519_ 1531. https://doi.org/10.1177/1352458519872889

82. Ellwardt E, Rolfes L, Klein J, Pape K, Ruck T, Wiendl H, Schroeter M, Zipp F, Meuth SG, Warnke C, Bittner S (2020) Ocrelizumab initiation in patients with MS: a multicenter observational study. Neurol Neuroimmunol Neuroinflammation. https://doi.org/ 10.1212/NXI.0000000000000719

83. Fox E, Lovett-Racke AE, Gormley M, Liu Y, Petracca M, Cocozza S, Shubin R, Wray S, Weiss MS, Bosco JA, Power SA, Mok K, Inglese M (2021) A phase 2 multicenter study of ublituximab, a novel glycoengineered anti-CD20 monoclonal antibody, in patients with relapsing forms of multiple sclerosis. Mult Scler 27(3):420-429. https://doi.org/10.1177/1352458520918375 